\title{
Copper-Catalyzed Asymmetric Mannich Reaction of Glycine Imines
}

<smiles>[R]C(N[TeH])C(N=[18O])C(=O)OC</smiles>

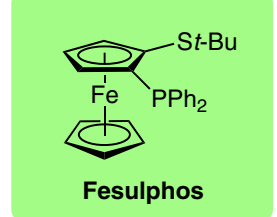

Selected examples:<smiles>CC(N[TeH])C(N=[18O])C(=O)OBr</smiles><smiles>CN=C(OC(C)(C)C)C(N[AsH3])C1CCCC1</smiles>

$74 \%$ yield dr > 98:2

$$
>99 \% \text { ee }
$$

$$
83 \% \text { yield }
$$$$
\mathrm{dr}>99: 1
$$$$
>99 \% \text { ee }
$$
$\mathrm{Ar}=\mathrm{Ph}$<smiles>CC/C=C/CCC(N=[18O])C(N[TeH])C(=O)OCC</smiles>

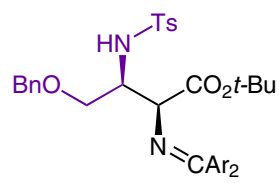<smiles>C=NC(CCCC)CN[18F]</smiles>

$$
\begin{gathered}
78 \% \text { yield } \\
\mathrm{dr}=90: 10 \\
>99 \% \text { ee } \\
\mathrm{Ar}=4-\mathrm{F}-\mathrm{C}_{6} \mathrm{H}_{4}
\end{gathered}
$$

$$
\begin{gathered}
50 \% \text { yield } \\
\mathrm{dr}=95: 5
\end{gathered}
$$$$
93 \% \text { ee }
$$$$
\mathrm{Ar}=4-\mathrm{F}-\mathrm{C}_{6} \mathrm{H}_{4}
$$

$80 \%$ yield

$83 \%$ ee
Ar $=4-\mathrm{F}-\mathrm{C}+\mathrm{H}_{4}$

\section{Proposed transition-state model:}

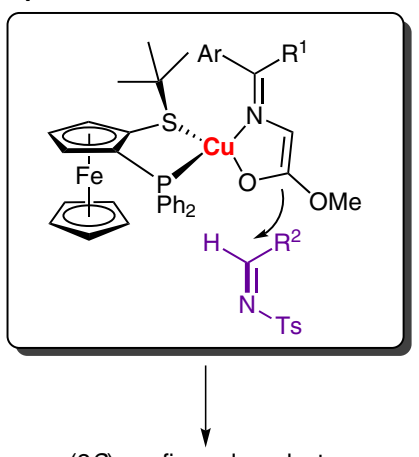

(2S)-configured products
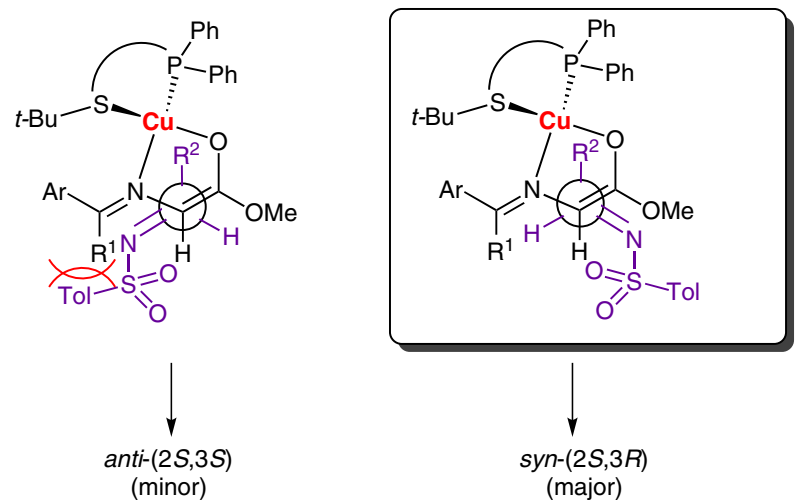

Significance: $\alpha, \beta$-Diamino acids are valuable due to their presence in peptide-based drugs and other bioactive compounds. In this report, the authors have extended their copper-catalyzed Mannich reaction of glycine Schiff bases to imines derived from aliphatic aldehydes, which previously performed poorly.
Comment: $\alpha$-Amido sulfones are employed as imine precursors, due to the instability of imines derived from aliphatic aldehydes. Excellent enantioselectivity and syn-selectivity is obtained for a variety of imines. The products have high synthetic applicability due to the orthogonal protection of the amines. 